had seen the form letter that went to the President's office saying, "Because requests for supplemental grants exceeded funds available, such grants to eligible institutions were reduced by approximately 25 per cent," we might have deduced that we weren't allowed that debatable fifth point we hoped to receive for "special circumstances." But the information in that letter to the President was never passed on to the library staff and it was only when I went to some meeting of librarians, and someone said, "There was only enough to cover 75 per cent of the requests," that I got the message.

Actually, the formula for computing the grants was 75.736 per cent of the figure derived from multiplying the number of FTE students in an institution by the number of points scored. The supplemental grants for which all the institutions qualified were totaled and compared with the amount available after the basic and special purpose grants were awarded. The resulting percentage figure was a fraction over 75 per cent. Among the 1,266 institutions receiving supplemental grants, 309 scored 5 points. Only 5 institutions rated the highest of 10 points.

On July 14, 1967 a letter from the Division of Library Services and Educational Facilities was sent to presidents of higher education institutions having library education programs, asking for an expression of interest and intent to hold institutes in library and information science in the summer of 1968 and/or the academic year 1968/69. The manual and application form will be sent early in November to those few institutions responding with a midDecember deadline specified.

We hope other institutions will respond to this excellent opportunity.

\section{CECL 1967}

Tentative program for the Conference of Eastern College Librarians on November 25 includes discussion on the subject of federal library services to college and research libraries by John Lorenz, Patricia Condon, Martin Cummings, and Russell Shank. The afternoon program will present Bernard Fry, director of the Clearing House for Federal, Scientific and Technical Information, on potential services to college and research libraries. Place: Harkness Theatre, Butler Library, Columbia University.

ACRL Membership, September 30, 1967, 12,226

September $30,1966,10,840$

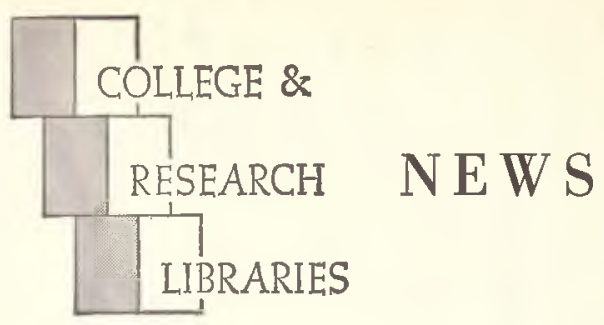

ACRL News Issue of College \& Research Libraries

Editor, David Kaser, Joint University Libraries, Nashville, Tenn. 37203.

Publications Officer, Mary Falvey, 50 E. Huron St., Chicago 60611.

ACRL Executive Secretary, George M. Bailey.

ACRL Officers, 1967/68: President, James Humphry III; College Libraries Section Chairman, Audrey North; Junior College Libraries Section, Mrs. Alice B. Griffth; Rare Books Section, Lawrence S. Thompson; Subject Specialists Section, Richard L. Snyder; Agriculture and Biological Sciences Subsection, Mrs. Pauline W. Jennings; Art Subsection, James K. Dickson; Law and Political Science Subsection, Morris Cohen; Slavic and East European Subsection, Jerzy (George) J. Maciuszko; University Libraries Section, Stuart Forth.

Editorial Board: John M. DAwson, University of Delaware; Gustave A. Harrer, Boston University; SaMUEL ROTHSTEIN, University of British Columbia; James E. Skrpper, Princeton University; Norman E. Tanis, Kansas State College of Pittsburg; Mauruce F. TAUBER, Columbia University; EIIEEN ThorNton, Oberlin College.

News from the Field, Personnel profiles and notes, classified advertising, official matter of ACRL, and other material of a timely nature is published in the News issues of College \& Research Libraries.

Inclusion of an article or advertisement in CRL does not constitute official endorsement by ACRL or ALA.

Production and Advertising and Circulation office: 50 E. Huron St., Chicago, Ill. 60611. Change of address and orders for subscriptions should be addressed to College of Research Libraries, for receipt at the above address, at least two months before the publication date of the effective issue.

Subscription to $C R L$ is included in membership dues to $A C R L$ of $\$ 6$ or more; other subscriptions to $C R L$ are $\$ 10$ per year. Neither subscriptions nor memberships include miscellaneous unscheduled supplements, which are available by purchase only. Retroactive subscriptions are not accepted. Single journal copies are available at $\$ 1.50$ each and News issues at $\$ 1.00$ each from ALA Publishing Department.

Indexed in Library Literature. Abstracted in Library Science Abstracts. Book reviews indexed in Book Review Index.

College \& Research Libraries, is the official journal of the Association of College and Research Libraries, a division of the American Library Association; and is published seventeen times per year-bi-montbly as a technical journal with 11 monthly News issues, combining July-August-at 1201-05 Bluff St., Fulton, Mo. 65251 .

Second-class postage paid at Fulton, Mo. and at additional mailing offices. 